\title{
Preservation of liquid semen and Artificial Insemination in native sheep
}

\author{
S. Pervage ${ }^{1}$, M. R. Hassan ${ }^{1}$, M. Ershaduzzaman ${ }^{1}$ and M. A. M. Y. Khandoker ${ }^{2}$ \\ ${ }^{1}$ Goat and Sheep Production Research Division, BLRI, Savar, Dhaka and ${ }^{2}$ Department of Animal Breeding and \\ Genetics, Bangladesh Agricultural University, Mymensingh-2202, Bangladesh
}

\begin{abstract}
An experiment was undertaken to determine the conception rate of native sheep by using Artificial Insemination with liquid ram semen. The semen was collected from ram using artificial vagina and the was stored in a refrigerator $\left(4^{\circ} \mathrm{C}\right)$ for three days. The volume of semen was extended with egg yolk citrate diluter. A total of 63 ewes were inseminated with stored liquid semen collected from 15 rams by AV method. The total number of spermatozoa, live-dead, normalabnormal, sperm motility and the $\mathrm{p}^{\mathrm{H}}$ was observed regularly. The average semen volume per ejaculate was 0.76 $1.00 \mathrm{ml}$ and the sperm concentration was $2.37 \times 109-4.30 \times 10^{9}$ per ejaculate. The number of normal spermatozoa and the $\mathrm{p}^{\mathrm{H}}$ was almost similar irrespective of days of storage. Number of live spermatozoa and the sperm motility were reduced with the increasing age of semen. The average conception rate (\%) was obtained as $63.61,61.90,52.38$ and 47.61 with sperm in zero, $1^{\text {st }}, 2^{\text {nd }}$ and $3^{\text {rd }}$ day storage respectively.
\end{abstract}

Keywords: Preservation, Liquid semen, Quality, Artificial insemination, Sheep

\section{Introduction}

There are about 2.47 million sheep in Bangladesh. Bangladeshi sheep are noted to be famous for their adaptability, fertility, prolificacy and disease resistance power. The native sheep is well adapted to hothumid climate and usually produces twins and triplets. Due to socio-economic reasons sheep raisers castrate almost all of their male lambs at early age. Consequently, there are severe short falls of breeding rams all over the country. Selected best quality rams could only be exploited through using artificial insemination (Al). But Al in sheep either with liquid or frozen semen is not yet popularized in Bangladesh. So, introducing Al with selected ram's semen could be the easiest source of popularizing desirable germplasm within short period. Moreover, by introducing systematic Al with unrelated ram it would be possible to reduce the inbreeding depression. Artificial Insemination is probably the most important single technique devised to facilitate the genetic improvement of animals. The widespread use of Al in sheep may allow accurate genetic evaluation and rapid dissemination of genetic merit on a national and international basis to bring benefit to the breeder and consumer. The use of liquid semen stored between $0-5^{\circ} \mathrm{C}$, allowing the semen for a longer period of time compared to fresh semen. The use of cooled semen has resulted in higher pregnancy rates when deposited at the cervix compared with frozen semen (Salmon and Maxwell, 2000). The availability of an efficient sheep Al service would greatly enhance the scope for pedigree and commercial breeders to respond positively and effectively to consumer demands. With the aim of preserving ram semen for performing Al for rapid genetic gain, the objectives of this study were set to evaluate semen quality of selected rams in terms of keeping quality and to determine the conception rate.

\section{Materials and Methods}

The experiment was conducted in Goat and Sheep Production Research Division farm, Bangladesh Livestock Research Institute (BLRI) from July 2008- April 2009. A total of 15 rams and 63 ewes were used in this experiment. Twenty-one ewes were inseminated with diluted liquid $\left(4^{0} \mathrm{C}\right)$ semen of either zero $(0), 1^{\text {st }}, 2^{\text {nd }}$ and $3^{\text {rd }}$ day storage. The animals were housed, ear tagged and reared under identical conditions of feeding, management and allowed to graze for 7-8 hours per day. Concentrate was offered twice daily at the rate of $200 \mathrm{~g}$ per head per day. All the animals were reared by semi-intensive system and housed in slatted floor permanent house. Rams were always kept separately from the ewes. Semen was collected from each ram twice a week. The volume of semen was measured with a calibrated collection vial. Sperm concentration was measured by haemocytometer method (Herman and Madden, 1963). The $\mathrm{pH}$ of semen was measured directly with the aid of nitragene paper while the individual motility of sperm was observed under microscope (Verberckmoes et al. 2001). Then the semen was mixed with diluter (Egg-yolk-citrate), fixed the sperm concentration at $300 \times 10^{6} / \mathrm{ml}$ and finally kept in a refrigerator $\left(4^{0} \mathrm{C}\right)$. The semen was further evaluated for its quality in zero $(0), 1^{\text {st }}, 2^{\text {nd }}$ and $3^{\text {rd }}$ days in terms of motility, pH; presence of live, dead and normal, abnormal sperm (Fig. 1 and 2). 
For counting the presence of live, dead sperm in the semen, one drop of eosin-nigrosin stain was placed on a clean glass slide. A small quantity of mixed semen was placed on the slide; spreaded by another slide and dried rapidly by placing them on a hot plate. Sperm head stained was counted as dead. Rose Bengal stain was used for counting the percentage of normal, abnormal sperm.

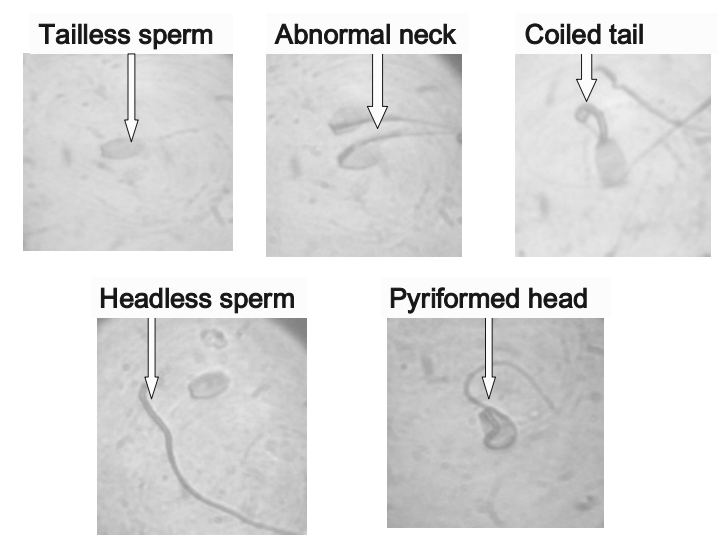

Fig. 1. Abnormal spermatozoa

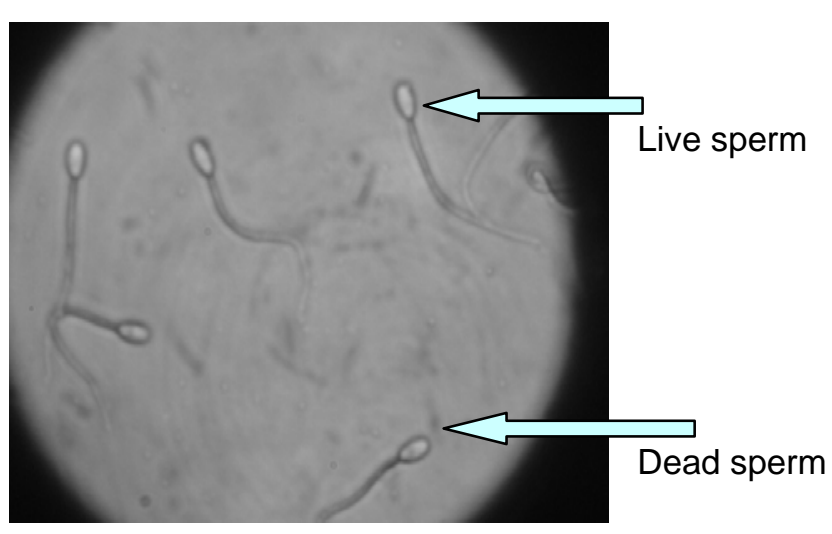

Fig. 2. Live and dead spermatozoa

Two drops of sodium-citrate buffer were placed on a clean dry glass slide; one drop of mixed semen was added and spreaded by covering with another slide. The slide was dried in the air and stained with rosebengal stain for 5 minutes, rinsed of excess stain by dipping the slide in distilled water. The slide with smear was dried in the air and observed under microscope in high magnification. After completion of microscopic evaluation, semen sample was diluted with egg-yolk citrate (each $100 \mathrm{ml}$ diluter contained $20 \mathrm{ml}$ egg-yolk, 80ml 2.94\% sodium-citrate buffer, penicillin @1000IU/ml, streptomycin @1000mg/ml, $6 \mathrm{mg} / \mathrm{ml}$ sulphanilamide powder), fixed the sperm concentration at $300 \times 10^{6} / \mathrm{ml}$ and kept in refrigerator $\left(4^{0} \mathrm{C}\right)$ up to three days. The diluted fresh semen at $1^{\text {st }}, 2^{\text {nd }}$ and $3^{\text {rd }}$ days of preservation were evaluated for sperm motility, $\mathrm{pH}$ and presence of live, dead and normal, abnormal sperm using the same procedure.

The estrus of the ewes was observed twice everyday with the aid of a vesectomized ram and inseminated after 12 hours from the onset of heat. The ewes that were in heat kept in pan separately. Cervical insemination was performed after 12 hours of showing the heat. Insemination with diluted semen was performed using pipette attached with a syringe without needle. Before the semen was expelled out of the insemination pipette, the speculum was removed to avoid pneumovagina and subsequent discharge of semen. Assumed conception rate was calculated on the basis of the ewes not coming into heat again within forty days. Data were treated and statistically analyzed by using Statistical Package for Social Science (SPSS, version 11.5). Mean comparisons were made using Duncan multiple range test (DMRT).

$$
\text { Assumed Conception rate }(\%)=\frac{\text { Number of ewes conceived }}{\text { Number of ewes inseminated }} \times 100
$$

\section{Results and Discussion}

The values for quality of raw semen are shown in Table 1 . The sperm concentrations of raw semen were $3.12 \times 10^{9}-4.30 \times 10^{9} / \mathrm{ml}$. The average volume of semen per ejaculate was $0.86 \mathrm{ml}$, which also supports the results of Menchaca et al. (2005), where they found $0.75-0.94 \mathrm{ml}$ of semen/ejaculate and the concentration was found $2.5 \times 10^{9}-3.92 \times 10^{9}$ sperm/ejaculate. The results obtained in this study revealed that freezing $\left(4^{\circ} \mathrm{C}\right)$ of semen has a negative effect on motility and the viability of spermatozoa. The percent of normal spermatozoa and $\mathrm{pH}$ were almost similar in $0,1^{\text {st }}, 2^{\text {nd }}$ and $3^{\text {rd }}$ days (Table 2 ). 
Table 1. Quality of raw semen

\begin{tabular}{|l|c|c|}
\hline Parameters & Values & $\begin{array}{c}\text { Values } \\
\text { (Mean } \pm \text { SE) }\end{array}$ \\
\hline Semen volume $(n=720)$ & $0.76-1.00 \mathrm{ml} /$ ejaculate & $0.864 \pm 0.23$ \\
\hline Sperm concentration $\left(\times 10^{9}\right.$ sperm/ml $(n=720)$ & $3.12-4.30$ & $3.52 \pm 0.90$ \\
\hline No. of spermatozoa $\left(x 10^{9}\right.$ sperm) per ejaculate $(n=720)$ & $2.37-4.30$ & $3.29 \pm 0.74$ \\
\hline
\end{tabular}

Table 2. Days of storage of semen, spermiogramic parameters and conception rate

\begin{tabular}{|c|c|c|c|c|c|}
\hline $\begin{array}{c}\text { Storage time } \\
(\mathrm{d})\end{array}$ & $\begin{array}{c}\text { Number of live sperm } \\
(\%)\end{array}$ & $\begin{array}{c}\text { Normal sperm } \\
(\%)\end{array}$ & Sperm motility (\%) & $\begin{array}{c}\text { pH } \\
\text { Conception } \\
\text { Rate }(\%)\end{array}$ \\
\hline 0 & $93.05 \pm 3.16^{\mathrm{a}}$ & $95.17 \pm 2.33^{\mathrm{a}}$ & $78.45 \pm 3.26^{\mathrm{a}}$ & $7.14 \pm 0.42^{\mathrm{a}}$ & 63.61 \\
\hline 1 & $91.05 \pm 2.29^{\mathrm{a}}$ & $94.28 \pm 1.62^{\mathrm{a}}$ & $76.45 \pm 2.82^{\mathrm{a}}$ & $7.10 \pm 0.33^{\mathrm{a}}$ & 61.90 \\
\hline 2 & $89.23 \pm 3.15^{\mathrm{a}}$ & $93.36 \pm 2.55^{\mathrm{a}}$ & $75.31 \pm 3.72^{\mathrm{a}}$ & $6.75 \pm 0.56^{\mathrm{a}}$ & 52.38 \\
\hline 3 & $81.33 \pm 2.19^{\mathrm{b}}$ & $93.09 \pm 2.78^{\mathrm{a}}$ & $70.53 \pm 2.56^{\mathrm{b}}$ & $6.50 \pm 0.45^{\mathrm{a}}$ & 47.61 \\
\hline
\end{tabular}

${ }^{a b c}$ Different superscripts in the same column indicate significant differences $(p>0.05)$

The conception rate obtained using first day diluted semen was comparatively higher $(61.90 \%)$ than the second (52.38\%) and third days (47.61\%) of insemination which also support the previous results of Boyd and Reed (1961) where they noted that the conception rate declined progressively with increasing age of semen from $65.4 \%$ for first day semen to $45.68 \%$ for ever third day. The conception rate obtained with fresh (o days) and first day semen was almost similar (Table2). Cervical artificial insemination (Al) using fresh ram semen has been widely used around the world (Gordon, 1983; Evans and Maxwel, 1987). Conception rate was found to be lower in ewes inseminated artificially compared to natural mating. This may be due to the failure of artificial insemination to provide a sufficient number of active sperm in the oviduct at the time of fertilization or some other factors. Conception rates with fresh or chilled semen are satisfactory (65 to $75 \%$ ) but miserably low (10 to 30\%) if frozen-thawed semen is used (Olesen, 1993). Erickson (2006) found 40 to $60 \%$ conception rate by using fresh and frozen semen of rams in anterior vagina. Culham et al. (2009) found approximately $75 \%$ conception rate from Al (Laparoscopic), which is very acceptable for this technology in the sheep industry but its application is limited by its expense, the required skills and the ethics of animal welfare. Paulenz et al. (2003) reported a 51.5\% lambing rate using semen stored at $5^{\circ} \mathrm{C}$ diluted in a commercial tris-based extender. Successful artificial insemination program involve multidimensional management including the detection of heat, proper time of insemination, semen storage method, handling and quality of semen, the efficiency of Al technician, ewes health, breed, feeding and others.

\section{Conclusion}

It can be concluded that acceptable conception rate may be obtained with artificial insemination using liquid ram semen stored at $4^{\circ} \mathrm{C}$ for 72 hours. However, for long term use (preservation) of ram semen effect of cryo-preservation and fertility assessment of the ewes inseminated with frozen semen need to be investigated.

\section{Acknowledgements}

We acknowledge the financial support of $\mathrm{GOB}$ funded national project entitle "Conservation and improvement of native sheep through community farming and commercial farming", Bangladesh Livestock Research Institute (BLRI), Savar, Dhaka.

\section{References}

Boyd, H. and Reed, H.C.B.1961. Investigation in to the incidence and causes of infertility in dairy cattle. Influence of some management factors affecting semen and insemination conditions. Brit. Vet.J. 117: 74-86.

Culham, A. and Hill, G. 2009. Sheep Teaching \& Research Center, Dept. of Animal Science, 1290 Anthony Hall, Michigan State University, 48824-1225

Erickson, G. 2006. Sheep Health, United Suffolk Sheep Association, Shepherd at Utah State University, Al in the Sheep Industry Today. 373 N. 200 W. Wellsville, Utah 84339 
Evans, G. and Maxwell, C. 1987. Salmon's artificial insemination of sheep and goats. Sidney: Butterworth pp. 66-76,158-161.

Gordon, I. 1983. Fixed time sheep artificial insemination. In: Controlled breeding in farm animals. Oxford, UK: Pergamon. pp. 197208.

Herman, H. A. and Madden, F. W. 1963. The artificial insemination of dairy and beef cattle: A handbook and laboratory manual. Lucas Brothers, Columbia, Missouri.

Menchaca, A; Pinczak, A. and Queirolo, D. 2005. Storage of ram semen at $5^{\circ} \mathrm{C}$ : effects of preservation period and timed artificial insemination on pregnancy rate in ewes. Anim. Reprod., volume2, n.3, p.195-198, Jul./Sept.

Olesen, I. 1993. Effects of cervical insemination with frozen semen on fertility and litter size of Norwegian sheep. Livestock Prod. Sci. 37: 169.

Paulenz, H; Soderquist, L; Adony, T; Fossen, O.H. and Anderson, B. K. 2003. Effect of milk and TRIS-based extenders on the fertility of sheep inseminated vaginally once or twice with liquid ram semen. Theriogenology, 60:759-766.

Salmon, S. and Maxwell, W.M.C. 2000. Storage of ram semen. Anim Reprod Sci, 62: 77-111.

Verberckmoes, S; Pauw, D.I; Soom, V.A; Vanroose, G; Leavens, H. and Kruif, A. 2001. A paper on Cervical Insemination in Sheep. Vlaams Diergeneeskundig Tijdschrift, 70, 475-480. 